\title{
ACTIVE LEARNING USING LEARNING MANAGEMENT SYSTEM TO IMPROVE STUDENTS' COMPETENCE IN ARGUMENTATIVE WRITING
}

\author{
Wardani Dwi Wihastyanang, Daning Hentasmaka, and Rosi Anjarwati \\ STKIP PGRI Jombang \\ dani_poobe@yahoo.com
}

\begin{abstract}
Nowadays the educational paradigm has changed from passive learning into active learning where learners are actively involved in teaching and learning process. Internet, as one of the information and communication products, is believed to be able to facilitate an active and interactive teaching and learning process. One of the examples is the use of Learning Management System (LMS). LMS is viewed appropriate to be applied in teaching English especially the writing skill in which learners need more time and more exercises to improve their skills. The limited time of classroom meeting makes the need impossible to be fulfilled. By using LMS, the teaching and learning process can not only depend on the classroom meeting but also can be done outside the classroom anytime and anywhere. In this quasi-experimental research the researchers were eager to know the effectiveness of active learning by using LMS to improve students' writing skill, especially in argumentative writing. The data was analyzed with ANCOVA using SPSS version 20. The result shows that the value of F-value is 5.505 and the significant value is .021 which is less than .05, and the F-value is higher than F-table (3.94). It means that the alternative hypothesis $\left(\mathrm{H}_{\mathrm{a}}\right)$ is accepted. Thus, it can be concluded that teaching writing by using LMS is more effective than conventional classroom meeting.
\end{abstract}

Keywords: active learning, Learning Management System (LMS), argumentative writing

Nowadays the educational paradigm has changed from passive learning into active learning where learners are actively involved in teaching and learning process in order to get more exercises and more experiences in the whole process of teaching and learning.

Learning, according to Higard \& Bower in Baharuddin (2010), is process of gaining or mastering knowledge through experiencing, memorizing, mastering experiences, and getting or finding information. Dale's cone of experiences (Dale, 1969) presented in the following figure shows the progression of experiences from the most concrete to the most abstract.

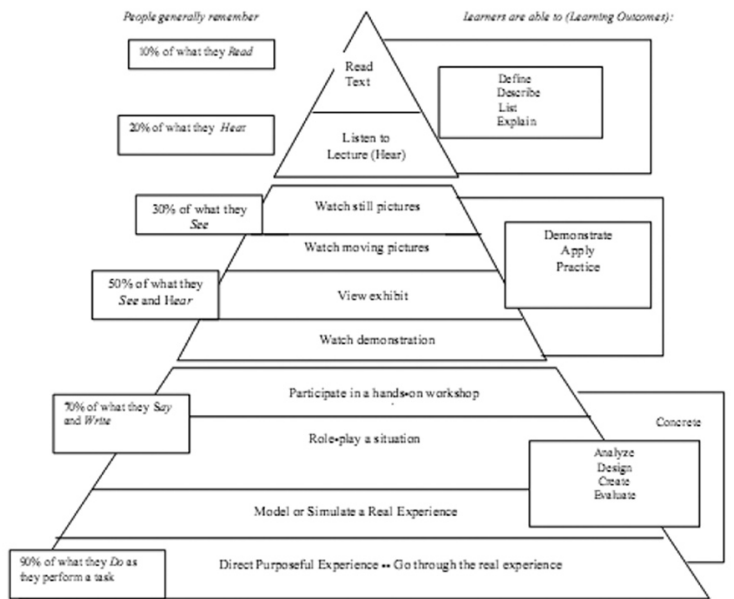

Figure 1. Dale's Cone of Experiences (Source: Adapted from E. Dale, Audiovisual Methods in Teaching, 1969, NY: Dryden Press) 
As illustrated in the figure, in active learning model learners have higher ability of memorizing what they have learned than in passive learning model. It is clear that the more concrete experiences learners have in learning process yield higher retention of the material learned; on the other hand, the more abstract experiences learners have yield lower retention. Hence, the active learning model is effective in giving concrete learning experiences to the learners.

Internetis believed to be able to facilitate an active and interactive teaching and learning process. One of the examples is the use of Learning Management System (LMS). Learning management system, according to Ellis (2009), is a software application for the administration, documentation, tracking, reporting and delivery of e-learning education courses or training. It is viewed appropriate to be applied in teaching English especially the writing skill in which learners need more time and more exercises to improve their skills.

For many years the teaching of writing focused on the written product rather than on the writing process (Harmer, 2007). Some of writing instruction process for example, expect learners to write a composition in the classroom which is then submitted and corrected by the teacher and handed back on the next meeting. But, most of learners rarely check the corrected pieces of work they have received. The illustration shows that the limited time of classroom meeting makes the learners' need of exercises and direct feedbacks are impossible to be fulfilled. By using LMS the teaching and learning process can not only depend on the classroom meeting but also can be done outside the classroom anytime and anywhere. So, the learners' attention will be directed not only to the what but also to the how of text construction.

\section{METHOD}

The research applied quasi experimental design to measure whether the use of Learning
Management System (LMS e-front) as media in teaching argumentative essay is effective or not. It included teaching argumentative essay using LMS as the independent variable and the result of the research in the form of the learners' writing achievement as the dependent variable.

The experimental and control groups selected were given treatments in different ways. The experimental group was taught argumentative essay by LMS e-front while the control group was taught without using LMS e-front with the same materials. At the end of the experiment the two groups were post-tested. The data collected were then analyzed with ANCOVA technique using SPSS 20 for windows.

\section{FINDINGS AND DISCUSSION}

\section{The Description of Pre-test Score}

The descriptive statistic of learners' pretest both of experimental and control group presented in a table below.

Table 1. Descriptive Statistics of Pre-test

\begin{tabular}{lllll}
\hline & $\begin{array}{l}\text { Teaching } \\
\text { Method }\end{array}$ & Mean & $\begin{array}{l}\text { Std. } \\
\text { Deviation }\end{array}$ & $\mathrm{N}$ \\
\hline Pretest & Without & 68.58 & 12.244 & 43 \\
Score & LMS & & & 43 \\
\cline { 2 - 5 } & LMS & 63.50 & 9.543 & 50 \\
\hline
\end{tabular}

The table of descriptive statistics shows that mean score of experimental group (in this case group which is taught writing by using LMS e-front) is 68.58 (s.d $=12.244$ ) and the control group (in this case group which is taught without using LMS e-front) is 63.50 (s.d. = 9.543). It means that group which is taught by using LMS e-front is actually better than the group taught without using LMS e-front.

\section{The Description of Post-test Score}

The descriptive statistic of learners' posttest both of experimental and control group presented in a table below. 
Table 2. Descriptive Statistics of Post-test

\begin{tabular}{llll}
\hline Teaching Media & Mean & $\begin{array}{l}\text { Std. } \\
\text { Deviation }\end{array}$ & $\mathrm{N}$ \\
\hline $\begin{array}{l}\text { Without LMS } \\
\text { e-front }\end{array}$ & 71.05 & 8.968 & 43 \\
\hline LMS e-front & 74.20 & 10.990 & 50 \\
\hline
\end{tabular}

The table of descriptive statistics of posttest shows that mean score of experimental group (in this case group which is taught writing by using LMS e-front) is 74.20 (s.d. = 10.990). The increase of mean score from pretest mean score of experimental group is 10.7 or $14.42 \%$ while the mean score of control group (in this case group which is taught without using LMS e-front ) is 71.05 (s.d. $=8.968$ ) and the increase of the mean score is 2.47 or $3.48 \%$. The increase of the mean score of teaching writing by using LMS e-front is higher than the group taught without using LMS e-front.

\section{Analysis of Covariance}

\section{Table 3. Tests of Between-Subjects Effects}

Dependent Variable: posttest (learners' achievement)

\begin{tabular}{llllll}
\hline Source & Type III Sum of Squares & df & Mean Square & F & Sig. \\
\hline Corrected Model & $1335.441^{\mathrm{a}}$ & 2 & 667.720 & 7.337 & .001 \\
\hline Intercept & 6361.287 & 1 & 6361.287 & 69.901 & .000 \\
\hline Media & 500.943 & 1 & 500.943 & 5.505 & .021 \\
\hline Pretest & 1105.541 & 1 & 1105.541 & 12.148 & .001 \\
\hline Error & 8190.366 & 90 & 91.004 & & \\
\hline Total & 501625.000 & 93 & & & \\
\hline Corrected Total & 9525.806 & 92 & & & \\
\hline
\end{tabular}

a. R Squared $=.140$ (Adjusted R Squared $=.121$ )

Based on the table of Tests of Between-Subjects Effects, it can be seen that the independent variable (in this case teaching argumentative essay using LMS) finds an F-value of the effect of teaching method 5.505 and column labeled Sig the value is .021 where it is less than 0.05 (an alternative alpha level). It means that two groups (both of experimental and control group) differ significantly.

In line pretest finds an F-value of the effect of pretest 12.148 column sig, the value is 0.01 . This is less than 0.05 , therefore the covariate is significant.

In the table of tests of between-subjects effects line teaching method shows that the value of F-value is 5.505 and the significant value is .021 which is less than .05 and the F-value is higher than F-table (3.94).Thus it can be concluded that both of experimental group and control group differ significantly. It means that the hypothesis (Ha) shows that there is a significant effect of learners' achievement who were taught writing by using LMS e-front. Thus, the Ho is rejected.

Based on the result of implementing teaching writing using LMS e-front, there was influence to the learners' achievement in writing. This statement is supported by the opinion of Harmer (2007) which stated that not only product approach that should be considered in teaching writing, but also the writing process. Active learning are purposed to keep students' focus on teaching and learning processes (Hartono, 2008:20) since in active learning model students do various activities (Silberman, 2010:9). They actively use their brain to learn new ideas, solving problems, and apply what they have learned. Those exist in the teaching-learning process by using LMS e-front. In teaching writing by using LMS e-font learners practiced the writing 
process especially in reflection and revision in which learner responded to each other's ideas in terms of language and content, gave suggestion to make changes and contributed to the success of finished product. By involving learners actively in designing and creating their own ideas and also analyzing and evaluating other's ideas increased learners' retention rates and improved their writing ability as illustrated by Dale (1969) in his cone of experience.

The use of LMS e-front as media of active learning model in teaching writing gives many benefits for both teacher and learners. Since writing is a long process it needs long time; LMS e-front helps teacher to save the time in delivering the material and also gives the flexibility for learners to practice. Learners are not only to be up-to-date on course material but also to be assimilated the material so they can use and build on it. When learners knew that the writing course involves active learning, they would also recognize that they have to be active if they want to be success in the course.

\section{REFERENCES}

Baharuddin \& Wahyuni. (2010). Teori Belajar dan Pembelajaran. Jogjakarta: Ar-Ruzz Media.

Dale, E. (1969). Audio-Visual Methods in Teaching, $3^{\text {rd }}$ ed. New York: Dryden Press.

Ellis, R.K. (2009). Field Guide to Learning Management Systems. ASTD Learning Circuits.

Harmer, J. (2007). The Practice of English Language
When learners learn actively, they retain more course content for a longer time and are able to apply that material in a broader range of contexts. From the research it was also found that there were some students are not actively involved in using LMS e-front. The major factor which causes this phenomenon is the limited access to internet.

\section{CONCLUSION}

Based on the result of the data analysis and discussion in the previous chapters, it shows that there is a significant difference between the mean scores of the learners in the control and the experimental groups. Therefore, the gain score in the experimental group led to the rejection of the null hypothesis, which stated the learners who are taught writing by using LMS e-front have higher score than those who are taught without using LMS e-front. In addition, Learning Management System (LMS e-front) can be an effective media in teaching writing especially in writing argumentative essay.

Teaching. Harlow: Pearson Education Limited.

Hartono. (2008). Strategi Pembelajaran Active Learning, URL: http://edu-articles. com/Situs Pendidikan Indonesia.html, (accessed on 10 December 2013)

Silberman, M. (2010). Active Learning 101 Cara Belajar Siswa Aktif. Bandung: Penerbit Nusamedia. 